\title{
Analisis Kandungan Air, Abu, dan Logam Berat Pada Kopi Bubuk Asal Gayo
}

\author{
Analysis of Water, Ash, and Heavy Metal Contents in Gayo Ground \\ COFFEE
}

Bhayu Gita Bhernama $^{1 *}$ dan Cut Nuzlia ${ }^{1}$

${ }^{1}$ Program Studi Kimia, Universitas Islam Negeri Ar-Raniry, Jln. Syeikh Abdurrauf Kopelma Darussalam, Banda Aceh

1*Pos el: deta.chavez1678@gmail.com

\begin{tabular}{|c|c|}
\hline ARTICLE INFO & Abstract \\
\hline Article history & Gayo coffee is one type of arabica coffee originating from the Gayo \\
\hline Received date: & plateau, Central Aceh district. Where Gayo coffee has a distinctive \\
\hline 2019-04-19 & $\begin{array}{l}\text { flavor, strong aroma and taste specifically. In the Gayo coffee process- } \\
\text { ing process, it is inseparable from various kinds of contamination, }\end{array}$ \\
\hline Received in revised form date: & so analysis needs to be done. Analysis was carried out on two coffee \\
\hline 2019-06-14 & samples taken from two factories, namely factories $A$ and $B$. Analysis \\
\hline Accepted date: & $\begin{array}{l}\text { carried out included analysis of water, ash, and metal content of ground } \\
\text { coffee originating from Gayo. The analysis of metal content was carried }\end{array}$ \\
\hline 2019-06-18 & out by using Atomic Absorbtion Spectroscopy (AAS). The test results \\
\hline Available online date: & d that coffee $A$ had a water content of $0.0397 \%$ and ash content \\
\hline & $4 \%$ while coffee $B$ had a water content of $0.01772 \%$ and ash content \\
\hline November 2019 & $\begin{array}{l}\text { 4.3\%. The test results of heavy metal within coffee } A \text { and } B \text { revealed } \\
\text { that the contaminants of } \mathrm{Cu}, \mathrm{Hg}, \mathrm{Pb} \text { and } \mathrm{Zn} \text { metals existed. The coffee } \\
\text { A contained } \mathrm{Cu} \text { and } \mathrm{Hg} \text { metal contamination with levels of } 6.4945 \text { and } \\
0.0029 \mathrm{mg} / \mathrm{Kg} \text { respectively. While, the coffee } \mathrm{B} \text { contained } \mathrm{Cu} \text { and } \mathrm{Hg} \\
\text { metal contamination with levels of } 7.6120 \text { and } 0.0042 \mathrm{mg} / \mathrm{Kg} \text {, respec- } \\
\text { tively. The contamination of } \mathrm{Pb} \text { and } \mathrm{Zn} \text { within the coffee } \mathrm{A} \text { and } \mathrm{B} \text { were } \\
\text { low and insignificant }(0.001 \mathrm{mg} / \mathrm{Kg}) \text {. From the results of the analysis, it } \\
\text { was found that the water, ash and metal content in coffee } \mathrm{A} \text { and coffee } \\
B \text { complies to the Indonesian National Standards (SNI) 01-3542-2004. }\end{array}$ \\
\hline
\end{tabular}

Kata kunci:

Aceh

Kopi Gayo

Logam Berat

Spektroskopi Serapan Atom

(SSA)

Keywords: Aceh, Gayo Coffee, heavy metal, Atomic Absorption Spectroscopy (AAS).

\begin{abstract}
Abstrak
Kopi Gayo merupakan salah satu jenis kopi arabika yang berasal dari dataran tinggi Gayo, kabupaten Aceh Tengah. Dimana kopi Gayo memiliki citarasa yang khas, yaitu aroma dan rasa yang kuat dan kental. Pada proses pengolahan kopi Gayo tidak terlepas dari berbagaimacam kontaminasi sehingga perlu dilakukan analisis. Analisis dilakukan terhadap dua sampel kopi yang diambil dari dua pabrik yaitu pabrik A dan B. Analisis yang dilakukan antara lain analisis kandungan air, abu dan logam terhadap kopi bubuk yang berasal dari Gayo. Analisis kandungan logam dilakukan dengan menggunakan Spektroscopy Serapan Atom (SSA). Hasil uji didapatkan kopi A memiliki kadar air 0,0397\% dan kadar abu 4\% sedangkan kopi B memiliki kadar air 0,01772\% dan kadar abu 4,3\%. Hasil uji cemaran logam kopi A dan B terdapat cemaran logam $\mathrm{Cu}, \mathrm{Hg}, \mathrm{Pb}$, dan $\mathrm{Zn}$. Dimana kopi A memiliki cemaran logam $\mathrm{Cu}$ dan $\mathrm{Hg}$ dengan kadar berturut-turut 6,4945 dan 0,0029 mg/Kg, sedangkan kopi B memiliki cemaran logam $\mathrm{Cu}$ dan $\mathrm{Hg}$ dengan kadar berturut-turut 7,6120 dan 0,0042 mg/Kg. Kontaminasi $\mathrm{Pb}$ dan $\mathrm{Zn}$ dalam kopi A dan kopi B dengan tingkat yang kecil $(0,001 \mathrm{mg} / \mathrm{Kg})$. Dari hasil analisis didapatkan kandungan air, abu, dan logam pada kopi A dan B memenuhi standar SNI 01-3542-2004
\end{abstract}




\section{PENDAHULUAN}

Coffea, $s p$ atau sering kita kenal dengan istilah Kopi adalah sumber daya alam Indonesia yang melimpah dalam bidang perkebunan. Peranan kopi di Indonesia salah satunya untuk meningkatkan perekonomian karena kopi merupakan komoditi ekspor yang cukup handal. Daerah produsen kopi yang terkenal di Indonesia adalah provinsi Aceh, tepatnya di Aceh Tengah, Gayo Luwes. (Putri, Fariyanti, \& Kusnadi, 2013). Aceh, terutama di kabupaten Aceh Tengah kaya akan produk pangan di antaranya kopi. Kopi yang sering dikenal adalah kopi Arabika Gayo. Produksi kopi dari daerah Gayo, Aceh Tengah ini merupakan pusat produksi terbesar kopi tidak hanya di Indonesia tetapi juga Asia dengan kualitas terbaik di dunia. Rosita, dkk. (2016) dalam artikelnya menjelaskan bahwa kopi asal Aceh tengah ini sering dikenal dengan kopi Arabika "Origin-Gayo" dikarenakan aroma dan cita rasa kopi yang khas dataran tinggi Gayo terdapat di daerah pegunungan Bukit Barisan yang terbentang di sepanjang pulau Sumatera dengan topografi yang ideal untuk perkebunan kopi, yaitu kondisi tanah yang subur berasal dari tanah vulkanik yang kaya unsur hara (Rosita, Rini, I Wayan Budiastra, 2016).

Kopi Gayo dalam istilah bahasa Inggris dikenal dengan Gayo coffee merupakan jenis kopi Arabika yang berasal dari Dataran Tinggi Gayo, Sumatra, Indonesia (Rosita, Rini, I Wayan Budiastra, 2016). Kopi gayo ini merupakan salah satu komoditas handal untuk meningkatkan perekonomian bangsa Indonesia pada umumnya dan untuk masyarakat Gayo pada khusunya. Sejak masa Indonesia dijajah oleh Belanda hingga saat ini, masyarakat Gayo menjadikan kopi Gayo sebagai mata pencaharian pokok dan daerah ini telah menjadi pusat penghasil kopi ekspor yang berkualitas dari daerah Aceh Tengah. Selain itu, bukti lain telah ditemukannya sisa pabrik pengeringan kopi masa kolonial Belanda di desa Wih Porak, kecamatan Silih Nara, Aceh Tengah menjelaskan bahwa kopi pada masa lampau pernah menjadi komoditas penting perekonomian masyarakat Gayo, Aceh Tengah (Wahyuni, Karim, \& Anhar, 2013). Kopi Arabika Gayo ini dikenal dunia dikarenakan memiliki cita rasa khas dengan ciri utamanya adalah aroma dan rasa kopi yang kompleks, kental dan kuat (Wahyuni dkk, 2013).

Proses pengolahan biji kopi menjadi bubuk kopi membutuhkan tahapan-tahapan memungkinkan adanya kontaminasi, baik secara kimia, fisika, atau biologi. Kontaminasi secara kimia, yaitu berupa tercemarnya bubuk kopi dengan beberapa jenis logam berat yang berbahaya bagi kesehatan, seperti logam $\mathrm{Cu}, \mathrm{Pb}, \mathrm{Zn}$, dan $\mathrm{Hg}$. Pigozzi, et, al., (2018) menyatakan bahwa logam berat merupakan salah satu unsur logam yang memiliki berat molekul yang tinggi. Logam berat ini biasanya terdapat pada golongan B pada sistem tabel periodik. Selain itu Pigozzi, et, al. (2018) juga menyatakan bahwa logam berat merupakan unsur yang paling berpotensi dalam pencemaran lingkungan serta berdampak kepada kesehatan manusia. Apabila pencemaran lingkungan seperti limbah cair dari pestisida, limbah rumah tangga yang terserap oleh tanah akan diserap oleh akar tanaman kopi dan menjadikan tanaman kopi tersebut mengandung logam berat. Logam berat ini apabila terakumulasi banyak pada bahan makanan dengan konsentrasi tinggi akan mengakibatkan racun dalam tubuh manusia. Pencemaran logam berat yang terdapat pada makanan, dapat terjadi pada saat proses produksi (Pigozzi et al., 2018). Oleh sebab itu, perlu dilakukan analisis logam berat yang terdapat pada bubuk kopi.

Dari penjelasan di atas, peneliti tertarik untuk melakukan analisis pencemaran logam yang terdapat pada bubuk kopi Gayo yang di produksi oleh industri menengah 
di kabupaten Aceh Tengah. Penelitian ini bertujuan untuk mengetahui apakah bubuk kopi Gayo mengandung bahan berbahaya logam berat

\section{METODE}

\section{Alat dan Bahan}

Bahan yang digunakan dalam penelitian ini antara lain dua sampel bubuk kopi Gayo, akuades dan $\mathrm{HNO}_{3} 39 \%$ (p).

Alat pada penelitian ini antara lain neraca analitik (Mark-M5-Ion), pipet gondok $5 \mathrm{ml}$ (Pyrex grade A), cawan porselen, labu ukur $100 \mathrm{ml}$ (Pyrex grade A), batang pengaduk, corong, kertas whatman 41, tanur, hote plate (Digital) RSH-1DR, dan AAS (Shimadzu AA 7000).

\section{Metode}

\section{Deskripsi Penelitian}

Sampel bubuk kopi Gayo pada penelitian ini diambil dari beberapa pabrik pengolahan kopi dari beberapa daerah di kabupaten Aceh Tengah yang kemudian diuji logam beratnya.

\section{Teknik Pengambilan Sampel}

Teknik pengambilan sampel pada penelitian ini menggunakan teknik purposive sampling, dimana sampel yang diambil adalah bubuk kopi dari dua pabrik pengolahan kopi di kabupaten Aceh Tengah.

\section{Uji Laboratorium}

Uji kimia kadar abu dan kadar air dilakukan berdasarkan SNI 01-3542-2004, sedangkan uji pencemaran logam pada kopi ini dilakukan berdasarkan SNI 01-2896-1998, yang sesuai dengan syarat mutu kopi yang telah ditetapkan. Pengujian dilakukan terhadap dua sampel kopi dari dua industri kecil penghasil kopi yaitu kopi A dan B.

\section{Uji Organoleptik}

Uji organoleptik dilakukan oleh lima orang penelis yang memiliki kualifikasi dan dipilih oleh peneliti. Uji organoleptik yang akan dilakukan berupa uji aroma, rasa, dan warna dari produk kopi Gayo. Sampel produk yang dianalisis sebanyak dua sampel yang berasal dari dua industri kopi di daerah Gayo, kabupaten Aceh Tengah.

\section{Uji kadar air}

Uji kadar air, yaitu prinsipnya kehilangan berat pada pemanasan $105^{\circ} \mathrm{C}$, yaitu ditimbang sampel sebanyak 1-2 gram pada botol timbangan tertutup yang sudah diketahui beratnya. Dikeringkan pada suhu $105{ }^{\circ} \mathrm{C}$ selama tiga jam, kemudian didinginkan dalam eksikator. lalu ditimbang. Hal terebut terus diulangi sehingga diperoleh berat tetap.

$$
\begin{aligned}
& \text { Perhitungan kadar air: } \\
& \text { kadar air }=\frac{\mathrm{w}}{\mathrm{w}_{1}} \times 100 \%
\end{aligned}
$$

$$
\begin{aligned}
\operatorname{dimana}: \mathrm{W}= & \begin{array}{l}
\text { Berat sampel sebelum } \\
\text { dikeringkan }(\text { gram })
\end{array} \\
\mathrm{W}_{1}= & \text { Berat sampel setelah } \\
& \text { dikeringkan (gram) }
\end{aligned}
$$

\section{Uji Kadar Abu}

Uji kadar abu pada prinsipnya adalah proses pengabuan zat organik yang diuraikan menjadi air dan $\mathrm{CO}_{2}$ kecuali bahan anorganik, yaitu ditimbang 2-3 gram sampel bubuk kopi ke dalam cawan porselen (cawan platina) yang telah diketahui beratnya terlebih dahulu. Kemudian diarangkan di atas nyala pembakar, lalu diabukan dalam tanur listrik pada suhu $550{ }^{\circ} \mathrm{C}$ sampai pengabuan sempurna kemudian idinginkan dalam desikator, lalu ditimbang sampai beratnya tetap. 
Perhitungan kadar abu:

$$
\text { kadar abu }=\frac{\mathrm{w}_{1}-\mathrm{W}_{2}}{\mathrm{~W}} \times 100 \%
$$

$$
\text { dimana: } \begin{aligned}
\mathrm{W}= & \text { berat sampel sebelum } \\
& \text { diabukan }(\text { gram }) \\
\mathrm{W}_{1}= & \text { berat sampel }+ \text { cawan } \\
& \text { sesudah diabukan }(\text { gram }) \\
\mathrm{W}_{2}= & \text { berat cawan kosong }(\mathrm{gram})
\end{aligned}
$$

\section{Uji pencemaran logam berat}

Dua sampel bubuk kopi Gayo masing-masing ditimbang dalam cawan porselen, kemudian di panaskan dengan hot plate hingga tidak ada asap lagi. Cawan porselen tersebut, kemudian dipindahkan ke dalam tanur dengan suhu $200{ }^{\circ} \mathrm{C}$, secara bertahap dinaikkan suhu hingga $550{ }^{\circ} \mathrm{C}$ selama dua jam dan diabukan semalam pada suhu $550{ }^{\circ} \mathrm{C}$. Cawan kemudian diangkat dan didinginkan dalam desikator. Apabila masih terdapat sisa karbon, setelah dingin ditambahkan $1 \mathrm{ml}$ akuades, selanjutnya dikeringkan di atas hot plate. Cawan tersebut dipanaskan kembali dalam tanur pada suhu $550{ }^{\circ} \mathrm{C}$ selama satu jam atau hingga berwarna putih. Setelah berwarna putih, ditambahkan $\mathrm{HNO}_{3} 39 \%$ (p) melalui dinding cawan porselen dan diaduk hingga abu larut. Proses selanjutnya disaring menggunakan kertas saring (Whatman-41) dan dipindahkan ke dalam labu ukur 100 $\mathrm{ml}$ lalu ditambahkan akuades hingga tanda batas. Sampel diukur menggunakan AAS yang kemudian dibandingkan dengan larutan standarnya.

\section{HASIL DAN PEMBAHASAN \\ Organoleptik, Kadar Air dan Abu Kopi Bubuk Gayo}

Hasil uji produk kopi A dan kopi B di laboratorium terdapat pada Tabel 1. Pada uji pendahuluan yang dilakukan untuk produk kopi gayo dimana kopi A dan B adalah diuji organoleptik terlebih dahulu. Uji organoleptik dilakukan oleh lima orang penelis dimana hasilnya merupakan penjumlahan dari penilaian setiap penelis. Penilaian dari setiap komponen tersebut dibagi tiga kategori, yaitu rendah, sedang, dan tinggi. Hasil uji organoleptik yang dilakukan oleh lima penelis dari kedua produk kopi tersebut, yaitu kopi A dan B yang terdiri atas uji keadaan aroma, rasa, dan warna. Uji organoleptik menunjukkan bahwa kedua produk kopi tersebut memiliki aroma dan warna yang sedang, yaitu aroma khas dari kopi dan berwarna coklat tua sebagaimana warna khas bubuk kopi. Proses terjadinya warna menurut Suryani \& Sasmita (2016) merupakan hasil proses karamelisasi dari gula sehingga timbulnya warna coklat tua. Aroma yang dihasilkan dari kopi sangat khas. Aroma khas kopi ini dihasilkan dari senyawa kafeol dan senyawa-senyawa lainnya, seperti aseton, furfural, trimetilamina, asam formiat, dan asam asetat (Suryani \& Sasmita, 2016).

Sementara pada uji rasa, kedua produk kopi memiliki rasa sebagaimana rasa khas kopi, namun produk kopi A memiliki rasa yang lebih tajam dibanding kopi B, dimana produk kopi A memberikan kesan rasa kopi tertinggal lebih lama dilidah setelah dikonsumsi. Rasa yang terbentuk dari bubuk kopi menurut Rohmah (2009) ditimbulkan dari proses degradasi karbohidrat, alkaloid, asam klorogenat, senyawa volatile, dan senyawa trigonelline. Rasa manis yang terdapat pada kopi berasal dari penguraian karbohidrat menjadi sukrosa dan gula sederhana. Rasa pahit pada kopi berasal dari sublimasi kafein yang membentuk kafeol. Selain itu, rasa pahit juga dipengaruhi oleh pemecahan senyawa mineral, kafein, asam klorogenat, tannin dan senyawa organik lainnya (Rohmah, 2009).

Selain itu, kopi Gayo memiliki nilai keasaman yang sedang dan kekentalan 
kopi yang kuat. Berdasarkan penelitian yang dilakukan oleh Wahyuni dkk. (2013) kondisi tanah berpengaruh terhadap nilai keasaman dan aroma kopi, serta curah hujan juga berpengaruh terhadap proses pengolahan kopi. Nilai keasaman suatu kopi merupakan tolak ukur dari ketersediaan kandungan unsur hara dan aktifitas mikroorganisme dalam tanah yang berpengaruh terhadap kualitas kopi.

Menurut Hayati, dkk (2012) bahwa aroma, warna, dan rasa memiliki peranan yang sangat penting dalam mutu hasil pangan. Hal ini dikarenakan kualitas yang baik dari aroma, rasa, dan warna akan meningkatkan keinginan konsumen untuk membeli hasil pangan dan memberikan kesan suka atau tidaknya konsumen terhadap hasil pangan tersebut. Hayati dkk. (2012) juga menyatakan warna dari bubuk kopi ditentukan oleh reaksi maillard. Reaksi maillard ini merupakan reaksi kondensasi asam amino dan protein dengan adanya glukosa.

Hasil uji kadar air dan abu pada kedua produk menunjukkan sedikit perbedaan, kopi A memiliki kadar air sebesar 0,0397\%, lebih tinggi dibanding kopi $\mathrm{B}$ dengan kadar air sebesar 0,01772\%. Sementara untuk kadar abu, kopi A memiliki kadar abu sebanyak 4\%, dimana angka ini lebih kecil dibanding kadar abu kopi B, yaitu 4,30\%. Perbedaan kadar air dan abu dari kopi A dan B dapat dipengaruhi oleh lama roasting dan suhu yang digunakan. Akan tetapi kadar air dan abu keduanya masih memenuhi standar maksimal SNI 01-35422004, yaitu berturut-turut kadar air dan abu sebesar 7 dan $5 \%$.

Wahyuni dkk. (2013) menyatakan bahwa bahan baku dari daerah asal dan lingkungan yang berbeda merupakan faktor eksternal yang memengaruhi kadar abu dalam biji kopi. Sementara menurut Towaha, et al. (2016) perbedaan kadar abu pada kopi disebabkan oleh mutu kopi.
Mutu kopi Gayo yang baik memiliki kandungan mineral lebih tinggi sehingga kadar abu yang dihasilkan akan semakin tinggi. Selain itu, menurut Edvan dkk. (2016) bahwa suhu dan lama penyangraian juga memengaruhi kadar abu pada kopi. Purwanto dkk. (2015for the presence of genes coding for enterotoxins (LT and ST1) juga menyatakan suhu dan lama penyangraian berpengaruh penting terhadap kadar air.

Edvan dkk. (2016) menyatakan bahwa kadar air menurun apabila suhu dan lama penyangraian meningkat. Hal ini disebabkan karena semakin besar perbedaan antara medium pemanas dengan bubuk kopi semakin cepat pula proses perpindahan panas dan semakin cepat pula penguapan air yang terjadi. Perubahan berat air terjadi ketika kandungan air yang terdapat dalam bubuk kopi tersebut telah sampai pada kondisi jenuh menyebabkan air yang terkadung dalam bubuk kopi tersebut berubah dari fase cair ke fase uap. Apabila lama penyangraian lebih besar akan mengakibatkan cita rasa kopi yang lebih baik (Edvan dkk., 2016). Selain itu, Purwanto dkk. (2015for the presence of genes coding for enterotoxins (LT and ST1) juga menjelaskan bahwa kadar air yang terdapat dalam kopi bubuk memengaruhi cita rasa, kesegaran, dan daya tahan kopi tersebut terhadap mikroorganisme. Pada proses pengolahan biji kopi menjadi kopi bubuk diharapkan kadar air yang dihasilkan rendah. Hal ini dikarenakan semakin rendah kadar air semakin rendah penyerapan uap air dari udara, juga semakin baik bubuk kopi tahan dari segala kerusakan yang ditimbulkan oleh mikroorganisme. Sebaliknya, apabila kadar air tinggi akan menimbulkan penggumpalan pada hasil pengolahan bubuk kopi tersebut (Purwanto dkk., 2015)for the presence of genes coding for enterotoxins (LT and ST1. Dari penelitian ini didapatkan kadar air yang rendah, yaitu kadar air pada kopi A dan B berturut-turut sekitar 
0,0397 dan 0,01772\% (sesuai standar SNI 01-3542-2004, yaitu kadar air maksimal 7\%). Hasil analisis kadar air dan kadar abu dapat dilihat pada Tabel 1.

\section{Logam Berat pada Kopi Bubuk Gayo}

Pengujian kadar logam dalam bubuk kopi sangat penting karena pada proses pengolahan bubuk kopi diindikasikan terdapatnya cemaran logam. Selain itu, pada tanaman kopi itu sendiri dapat menyerap logam yang terkandung dalam tanah, akar tanaman yang menyerap logam, dan kemudian mengantarkannya ke daun dan biji kopi (Sabrina dkk., 2017).

Pada Tabel 1 dapat dilihat kandungan cemaran logam $\mathrm{Pb}, \mathrm{Sn}, \mathrm{Cu}, \mathrm{Zn}, \mathrm{Hg}$, dan As yang terdapat pada dua sampel kopi, yaitu sampel Kopi A dan B. Pemeriksaan cemaran logam $\mathrm{Cu}$ dan $\mathrm{Hg}$ pada kedua produk juga menunjukkan sedikit perbedaan. Kopi A memiliki kadar logam $\mathrm{Cu}$ dan $\mathrm{Hg}$ berturut-turut sebesar 6,4945 dan 0,0029 mg/Kg sementara kopi B memiliki kadar yang lebih tinggi, logam $\mathrm{Cu}$ dan $\mathrm{Hg}$ berturut-turut sebesar 7,6120 dan 0,0042 $\mathrm{mg} / \mathrm{Kg}$. Selain cemaran $\mathrm{Cu}$ dan $\mathrm{Hg}$, jumlah cemaran logam $\mathrm{Pb}$ dan $\mathrm{Zn}$ pada kedua produk sangat kecil, yaitu sebesar 0,0001 $\mathrm{mg} / \mathrm{Kg}$. Tingginya kandungan logam yang terdapat di dalam bubuk kopi memerlukan perhatian khusus karena logam yang terdapat pada bubuk kopi yang diminum oleh manusia akan meningkatkan kandungan logam yang terdapat dalam tubuh (Nędzarek et al., 2013).
Tabel 1. Hasil Uji Laboratorium Produk Kopi A dan Kopi B berdasarkan SNI 01-3542-2004

\begin{tabular}{|c|c|c|c|c|c|}
\hline No. & $\begin{array}{c}\text { Variabel } \\
\text { Uji** }^{* *}\end{array}$ & Satuan & Baku Mutu & $\begin{array}{c}\text { Hasil Uji } \\
\text { Kopi A }\end{array}$ & $\begin{array}{l}\text { Hasil Uji } \\
\text { Kopi B }\end{array}$ \\
\hline \multirow[t]{4}{*}{1.} & \multicolumn{5}{|c|}{ Keadaan: } \\
\hline & Aroma & - & Normal & $\begin{array}{c}\text { Sesuai } \\
\text { standar } \\
\text { baku mutu }\end{array}$ & $\begin{array}{c}\text { Sesuai } \\
\text { standar } \\
\text { baku mutu }\end{array}$ \\
\hline & Rasa & - & Normal & $\begin{array}{c}\text { Sesuai } \\
\text { standar } \\
\text { baku mutu }\end{array}$ & $\begin{array}{c}\text { Sesuai } \\
\text { standar } \\
\text { baku mutu }\end{array}$ \\
\hline & Warna & - & Normal & $\begin{array}{c}\text { Sesuai } \\
\text { standar } \\
\text { baku mutu }\end{array}$ & $\begin{array}{c}\text { Sesuai } \\
\text { standar } \\
\text { baku mutu }\end{array}$ \\
\hline 2. & Air & $\% \mathrm{~b} / \mathrm{b}$ & Maks. 7 & 0,0397 & 0,01772 \\
\hline 3. & Abu & $\% \mathrm{~b} / \mathrm{b}$ & Maks. 5 & 4,00 & 4,30 \\
\hline 4. & Kadar Abu & & $57-64$ & $\begin{array}{c}\text { Tidak } \\
\text { dilakukan }\end{array}$ & $\begin{array}{c}\text { Tidak } \\
\text { dilakukan }\end{array}$ \\
\hline 5. & Sari Kopi & $\% \mathrm{~b} / \mathrm{b}$ & $20-36$ & $\begin{array}{c}\text { Tidak } \\
\text { dilakukan }\end{array}$ & $\begin{array}{c}\text { Tidak } \\
\text { dilakukan }\end{array}$ \\
\hline 6. & $\begin{array}{c}\text { Kafein } \\
\text { (anhidrat) }\end{array}$ & $\% \mathrm{~b} / \mathrm{b}$ & $0,9-2$ & $\begin{array}{c}\text { Tidak } \\
\text { dilakukan }\end{array}$ & $\begin{array}{c}\text { Tidak } \\
\text { dilakukan }\end{array}$ \\
\hline 7. & $\begin{array}{c}\text { Bahan- } \\
\text { bahan Lain }\end{array}$ & - & $\begin{array}{c}\text { Tidak boleh } \\
\text { ada }\end{array}$ & - & - \\
\hline \multirow[t]{7}{*}{8.} & \multicolumn{5}{|c|}{ Cemaran Logam: } \\
\hline & Timbal (Pb) & $\mathrm{mg} / \mathrm{Kg}$ & Maks. 2,0 & 0,0001 & 0,0001 \\
\hline & $\begin{array}{l}\text { Tembaga } \\
\text { (Cu) }\end{array}$ & $\mathrm{mg} / \mathrm{Kg}$ & Maks. 30,0 & 6,4945 & 7,6120 \\
\hline & Seng (Zn) & $\mathrm{mg} / \mathrm{Kg}$ & Maks. 40,0 & 0,0001 & 0,0001 \\
\hline & Timah (Sn) & $\mathrm{mg} / \mathrm{Kg}$ & $\begin{array}{c}\text { Maks. } \\
40,0 / 250,0^{*}\end{array}$ & $\begin{array}{c}\text { Tidak } \\
\text { terdapat } \\
\text { cemaran } \\
\text { Timah (Sn) }\end{array}$ & $\begin{array}{c}\text { Tidak } \\
\text { terdapat } \\
\text { cemaran } \\
\text { Timah (Sn) }\end{array}$ \\
\hline & Raksa (Hg) & $\mathrm{mg} / \mathrm{Kg}$ & Maks. 0,03 & 0,0029 & 0,0042 \\
\hline & Arsen (As) & $\mathrm{mg} / \mathrm{Kg}$ & Maks. 1,0 & $\begin{array}{c}\text { Tidak } \\
\text { terdapat } \\
\text { cemaran } \\
\text { Arsen (As) }\end{array}$ & $\begin{array}{c}\text { Tidak } \\
\text { terdapat } \\
\text { cemaran } \\
\text { Arsen (As) }\end{array}$ \\
\hline \multicolumn{6}{|c|}{ * Untuk yang dikemas dalam kaleng } \\
\hline
\end{tabular}

Kandungan logam yang terdapat pada sampel kopi bubuk asal Gayo ini disebabkan pada proses pengolahan (produksi) dari awal produksi hingga akhir produksi. Kadar logam pada bubuk kopi A dan kopi B dapat dilihat pada Tabel 1.

Dari hasil uji cemaran logam yang terdapat pada produk kopi Gayo, yaitu kopi A dan B, masih di bawah ambang batas SNI 01-3542-2004. Batas maksimal untuk cemaran logam pada bubuk kopi, yaitu berturut-turut $\mathrm{Pb} ; \mathrm{Cu} ; \mathrm{Zn}$; $\mathrm{Sn} ; \mathrm{Hg}$; dan As sebesar 2,0; 30,0; 40,0; 40,0/250,0; 0,03; dan 1,0 mg/Kg. Dari uraian di atas 
menunjukkan bahwa kopi A dan B yang berasal dari dataran tinggi Gayo ini masih aman dikonsumsi dan layak untuk diperdagangkan.

\section{KESIMPULAN}

Dari hasil analisis laboratorium kopi A dan B memenuhi standar SNI 01-3542-2004. Kopi A dengan kadar air 0,0397\% dan kadar abu 4\% sedangkan kopi B memiliki kadar air 0,01772\% dan kadar abu 4,3\%. Hasil uji cemaran logam kopi A dan B terdapat cemaran logam $\mathrm{Cu}, \mathrm{Hg}, \mathrm{Pb}$ dan $\mathrm{Zn}$. Kopi A memiliki cemaran logam $\mathrm{Cu}$ dengan kadar 6,4945 mg/Kg, Hg 0,0029 mg/ $\mathrm{Kg}$, sedangkan kopi B memiliki cemaran logam $\mathrm{Cu}$ dengan kadar 7,6120 mg/Kg dan $\mathrm{Hg} 0,0042 \mathrm{mg} / \mathrm{Kg}$. Cemaran logam $\mathrm{Pb}$ dan Zn masing-masing kopi A dan B memiliki kadar yang kecil 0,0001 mg/Kg, sehingga dapat disimpulkan bahwa kopi A dan kopi $B$ yang berasal dari dataran tinggi Gayo ini layak untuk dikonsumsi dan diperdagangkan.

\section{UCAPAN TERIMA KASIH}

Penulis mengucapkan terima kasih kepada Lembaga Penelitian dan Pengabdian Masyarakat UIN Ar-raniry yang telah memberikan bantuan dana pada tahun 2016 dalam penyelesaian penelitian hingga menulis artikel ini.

\section{DAFTAR PUSTAKA}

Edvan, B.T., R. Edison, dan M. Same. 2016. "Pengaruh Jenis dan Lama Penyangraian Pada Mutu Kopi Robusta (Coffea Robusta)." Jurnal Agroindustri Perkebunan 4(1): 3140.
Hayati, Rita, Marliah. A, dan Rosita. F. 2012. "Sifat Kimia Dan Evaluasi Sensori Bubuk Kopi Arabika." Floratek, 66-75.

Nędzarek, Arkadiusz, Tórz. A, Karakiewicz. B, J. S. Clark, Laszczyńska. M, Kaleta. A, and Adler. G. 2013. "Concentrations of Heavy Metals ( $\mathrm{Mn}, \mathrm{Co}, \mathrm{Ni}, \mathrm{Cr}, \mathrm{Ag}, \mathrm{Pb}$ ) in Coffee" Acta Biocimica Polonica., 60 (4): 623-627.

Nurhayati, dan Sabarni. 2018. "Analisis Kadar Kafein dalam Minuman Kopi Khop dengan Metode Spektroskopik." Lantanida Journal 6 (2): 103-202.

Pigozzi, Mariana Teixeira, Flávia Regina Passos, and Fabrícia Queiroz Mendes. 2018. "Quality of Commercial Coffees: Heavy Metal and Ash Contents." Journal of Food Quality 2018: 1-7. https://doi. org/10.1155/2018/5908463.

Purwanto, Heri. E, Rubiyo, dan Juniaty Towaha. 2015. "Karakteristik Mutu Dan Citarasa Kopi Robusta KLON BP 42,BP 385 Dan 308 Asal Bali Dan Lampung." Sirinov 3(2): 67-74. https://doi.org/03781135(95)00108-M [pii].

Putri, Amelia. M, Fariyanti. A, dan Kusnadi. N. 2013. "Struktur Dan Integrasi Pasar Kopi Arabika Gayo Di Kabupaten Aceh Tengah Dan Bener Meriah," Buletin Ristri 4(1): 47-54.

Rohmah, dan Miftakhur. 2009. "Kajian Sifat Kimia Fisik Dan Organoleptik Kopi Robusta (Coffea Cannephora), Kayu Manis (Cinnamomun Burmanii) Dan Campurannya." Jurnal Teknologi Pertanian 4 (2): 75-83.

Rosita, Rini, I W. Budiastra, dan Sutrisno. 2016. "Prediksi Kandungan Kafein Biji Kopi Arabika Gayo Dengan Near Infrared Spectroscopy." Jurnal Keteknikan Pertanian 4(2): 179-186. https://doi.org/10.19028/ jtep.04.2.179-186. 
Sabrina, Alves da Silva, Queiroz Mendes Fabrícia, Rodrigues Reis Marcelo, Regina Passos Flavia, Mundstock Xavier de Carvalho Andre, Rodrigues de Oliveira Rocha Katia, and Garcia Pinto Frederico. 2017. "Determination of Heavy Metals in the Roasted and Ground Coffee Beans and Brew." African Journal of Agricultural Research 12 (4): 221-28. https://doi. org/10.5897/AJAR2016.11832.

Suryani, Nani, dan Sasmita. E.. 2016. "Kadar Kafein Pada Kopi Kemasan dan Uji Organoleptis Terhadap Aroma serta Rasa" Jurnal Scientia Pharmaceutica 2(2) : 9-14.
Towaha, Juniaty, Aunillah. A, Purwanto. E. H., dan Handi Supriadi. 2016. "Pengaruh Elevasi Dan Pengolahan Terhadap Kandungan Kimia Dan Citarasa Kopi Robusta Lampung." Jurnal Tanaman Industri Dan Penyegar 1 (1): 57. https://doi.org/10.21082/ jtidp.v1n1.2014.p57-62.

Wahyuni, Eka, Karim. A, dan Anhar. A.. 2013. "Analisis Citarasa Kopi Arabika Organik Pada Beberapa Ketinggian Tempat Dan Cara Pengolahannya Di Datararan Tinggi Gayo." Jurnal Manajemen Sumberdaya Lahan 2(3): 261-269. 